\title{
Kerentanan larva Aedes aegypti di Jawa Timur terhadap Temephos komersial dengan dosis berbeda
}

\author{
Susceptibility of Aedes aegypti larvae in East Java towards commercial Temephos at \\ different doses
}

\author{
Firas Khaleyla $^{1 *}$, Etik Ainun Rohmah², Kris Cahyo Mulyatno ${ }^{2}$ \\ 1) Jurusan Biologi, Fakultas Matematika dan Ilmu Pengetahuan Alam, Universitas Negeri Surabaya, Surabaya, Indonesia \\ 2) Laboratorium Entomologi, Lembaga Penyakit Tropis, Universitas Airlangga, Surabaya, Indonesia \\ *Email: firaskhaleyla@unesa.ac.id
}

Diterima 24 Desember 2020 Disetujui 3 September 2021

\section{INTISARI}

Pengendalian populasi nyamuk Ae. Aegypti di Indonesia dilakukan sebagai upaya untuk menekan penularan virus dengue, salah satunya dengan penaburan larvasida temephos. Dosis operasional penggunaan temephos di Indonesia (1 mg/L) lebih tinggi dibandingkan dosis yang disarankan World Health Organization (WHO) (0,012 mg/L). Di Jawa Timur, terdapat temephos yang beredar komersial dengan perbedaan pada dosis penggunaan, yaitu10 gram/100 L air $(10 \mathrm{G})$ dan 8 gram/100 L air (8G). Penelitian ini dilakukan untuk memeriksa kerentanan populasi larva Ae. aegypti yang berasal dari Jember (JEM), Surabaya (SBY), dan koleksi Laboratorium Entomologi Universitas Airlangga (LAB) terhadap temephos 10G dan 8G pada dosis pemakaian tinggi $(1 \mathrm{mg} / \mathrm{L})$ hingga rendah $(0,015625 \mathrm{mg} / \mathrm{L})$. Uji mortalitas pada larva dilakukan sesuai dengan ketentuan WHO dengan replikasi 4 kali. Data dianalisis secara statistik. Hasil menunjukkan bahwa ketiga kelompoklarva Ae. aegypti mengalami $>90 \%$ mortalitas dengan penambahan temephos pada dosis rendah $(0,015625 \mathrm{mg} / \mathrm{L})$ pada ambang waktu 240 menit, baik untuk temephos $10 \mathrm{G}$ maupun $8 \mathrm{G}$. Perbedaan respon mortalitas yang signifikan antara dosis tertinggi $(1 \mathrm{mg} / \mathrm{L})$ dan dosisterendah $(0,015625 \mathrm{mg} / \mathrm{L})$ ditemukan pada kelompok JEM pada dosis $8 \mathrm{G}$ dan $10 \mathrm{G}$ serta LAB pada dosis $8 \mathrm{G}$. Kelompok JEM dan SBY memiliki rasio resistensi $95\left(\mathrm{RR}_{95}\right)$ temephos dengan kategori rendah $(<5)$ dibandingkan dengan kelompok LAB. Semua kelompok masih memiliki kerentanan pada temephoskomersial pada dosis rendah $(0,015625 \mathrm{mg} / \mathrm{L})$. Dari hasil penelitian ini, kami menyarankan untuk menurunkan dosis operasional larvasida temephos yang digunakan untuk pengendalian populasi larva Ae. aegypti di Jawa Timur.

Kata kunci: Aedes aegypti, larvasida, temephos, Surabaya, Jember

\begin{abstract}
Control of Ae. Aegypti population is performed as an effort to suppress the transmission of dengue virus, one of the methods is sprinkling of temephos larvicide. Operational dose of temephos used in Indonesia (1 $\mathrm{mg} / \mathrm{L})$ is higher from recommended dose of WHO $(0.012 \mathrm{mg} / \mathrm{L})$. In East Java, commercial temephos are found to have different application doses of $8 \mathrm{~g} / \mathrm{L}(8 \mathrm{G})$ and $10 \mathrm{~g} / \mathrm{L}(10 \mathrm{G})$. This study was designed to know the susceptibility of Ae. aegypti population from Jember (JEM), Surabaya (SBY), and Entomology Laboratory of Universitas Airlangga collection (LAB) towards temephos 8G and 10G starting at high (1 $\mathrm{mg} / \mathrm{L})$ to low concentrations $(0.015625 \mathrm{mg} / \mathrm{L})$. Larvae mortality test was performed based on WHO standard method with 4 times replication. Data was analyzed statistically. Results showed that the three groups of
\end{abstract}


Ae. aegypti larvae had mortality level at $>90 \%$ in the lowest concentration applied $(0.015625 \mathrm{mg} / \mathrm{L})$ at time threshold of 240 minutes, for both temephos $8 \mathrm{G}$ and $10 \mathrm{G}$. Significant difference of larvae mortality towards highest $(1 \mathrm{mg} / \mathrm{L})$ and lowest dose $(0.015625 \mathrm{mg} / \mathrm{L})$ was found in JEM, at both $8 \mathrm{G}$ and $10 \mathrm{G}$ doses, and $\mathrm{LAB}$ at $8 \mathrm{G}$ dose. JEM and SBY groups were found to have resistance ratio $95\left(\mathrm{RR}_{95}\right)$ to temephosat low category $(<5)$ compared to LAB. All groupstill retained susceptibility towards commercial temephos larvicide at low dose $(0.015625 \mathrm{mg} / \mathrm{L})$. Based on results, we recommendedlowering the operational dose of larvicide temephos used for population control of Ae. aegypti vector population in East Java.

Keywords: Aedes aegypti, larvicide, temephos, Surabaya, Jember

\section{PENDAHULUAN}

Nyamuk Aedes aegypti telah lama dikenal sebagai vektor yang berperan menyebarkan berbagai macam virus yang menyebabkan penyakit pada manusia, misalnya virus dengue, chikungunya, yellow fever, serta Zika (Ding et al., 2018). Persebaran Ae. aegypti ditemukan paling tinggi adalah di daerah tropis (Ding et al., 2018; Kraemer et al., 2015), tidak terkecuali di Indonesia. Di Indonesia, Ae. aegypti terutama berperan dalam menularkan penyakit demam berdarah dengue (DBD). Hingga saat ini, penyakit DBD masih menjadi masalah untuk kesehatan masyarakat Indonesia karena jumlah penderitanya yang cukup tinggi dari tahun ke tahun. Pada tahun 2018, kasus DBD yang terjadi di Indonesia berjumlah 65.602 dengan tingkat kejadian per 100.000 penduduk sebanyak 24,75 dan jumlah kasus meninggal sebanyak 467 (Kemenkes RI, 2019). Di Jawa Timur sendiri, jumlah kasus DBD selama tahun 2018 adalah 8.449 dengan jumlah kasus meninggal sebanyak 84dancase fatality rate (CFR) sebesar 0,99\% yang mendekati kategori tinggi (CFR > 1\%)(Kemenkes RI, 2019). Surabaya adalah salah satu kota di Indonesia yang merupakan endemikDBD dan memiliki CFR yang berfluktuasi antara tahun 2009-2017(Tang et al., 2020).

Salah satu upaya untuk menekan penularan virus dengue adalah dengan mengendalikan populasi vektor pembawa virus. Berbagai usaha untuk mengendalikan populasi Ae. aegypti yang telah dilakukan di Indonesia, misalnya $3 \mathrm{M}$ plus (draining, covering, burying or recycling), penggunaan penolak nyamuk berbasis bahan kimia aromatik, memelihara ikan predator larva nyamuk, dan yang paling populer adalah dengan penambahan larvasida pada lokasi-lokasi yang menjadi preferensi Ae. aegypti untuk meletakkan telurnya (Haryanto, 2018).Hingga pada tahun 2018, Angka Bebas Jentik (ABJ) yang digunakan sebagai indikator pengendalian larva nyamuk di Indonesia masih belum mencapai target ( $\geq 95 \%)$, akan tetapi justru mengalami penurunan pada jangka waktu tahun 2016 (68,6\%) hingga 2018 (31,5\%) (Kemenkes RI, 2019).

Larvasida yang selama ini banyak digunakan untuk pengendalian populasi jentik nyamuk di Indonesia adalah larvasida sintetik komersil dari jenis organophosphatetemephos. World Health Organization (WHO) menyarankan dosis penggunaan temephospada $0,012 \mathrm{mg} / \mathrm{L}$, akan tetapidosis operasional temephos yang digunakan di Indonesia jauh lebih tinggi, yaitu 1 mg/L(Haryanto, 2018; Mulyatno et al., 2012). Di Jawa Timur, temephos komersialditemukan beredar dengan perbedaan pada saran konsentrasi penggunaan, yaitu 10 gram/10 liter air (10G) dan 8 gram/100liter air (8G).

Akibat penggunaannya yang terus menerus dan ekstensif di Indonesia, kerentanan larva $A e$. aegypti terhadap temephos komersial sebaiknya diperiksa secara rutin sebagai bentuk pengawasan untuk memastikan dosis yang digunakan tetap efektif. Penelitian ini dilakukan untuk memeriksa kerentanan populasi larva Ae. aegypti yang berasal dari daerah berbeda (endemik dan nonendemik DBD) di Jawa Timur terhadap temephos yang beredar secara komersial dengan perbedaan pada dosis yang disarankan.

\section{MATERI DAN METODE}




\section{Koleksi Sampel Larva}

Sampel Aedes aegypti yang digunakan berasal dari tiga populasi berbeda. Sampel dari daerah tidak rentan DBD diambil dari kelurahan Patrang, Kecamatan Patrang, Kota Jember (JEM), sedangkan sampel dari daerah rentan DBD diambil dari Kelurahan Sawahan, Surabaya (SBY). Sampel ketiga adalah koleksi Laboratorium Entomologi, Lembaga Penyakit Tropis, Universitas Airlangga (LAB) sebagai populasi pembanding. Larva Ae. aegypti dikoleksi dari daerah sampling dibawa ke laboratorium Entomologi, Lembaga Penyakit Tropis Universitas Airlangga untuk dipelihara sampai dewasa sebagai generasi pertama $\left(\mathrm{F}_{1}\right)$. Ae. aegypti dewasa dibiakkan hingga menghasilkan

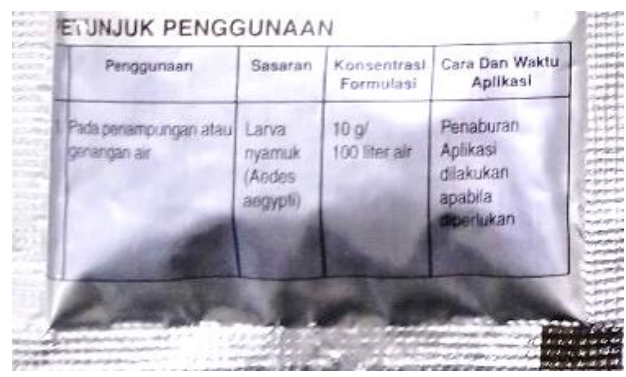

(a) generasi keturunan. Waktu yang dibutuhkan larva menjadi dewasa hingga generasi pertama selama seminggu, dalam kondisi terkontrol (kelembaban ruangan $75 \%$, temperatur air $28^{\circ} \mathrm{C}-30^{\circ} \mathrm{C}$, temperatur ruangan $28^{\circ} \mathrm{C}$ ).

\section{Larvasida Organophosphat Temephos}

Larvasida yang digunakan adalah organophosphatetemephos yang beredar secara komersil di Indonesia dengan merk Abate $1 \mathrm{G} \AA$ (Baden Aniline and Soda Manufacturing, Ludwigshafen, Germany) mengandung 1\% temephos. Dua jenis temephos komersial didapatkan dengan perbedaan pada saran dosis penggunaan, yaitu 10 gram/100 liter air (10G) dan 8 gram/100 liter air (8G) (Gambar 1).

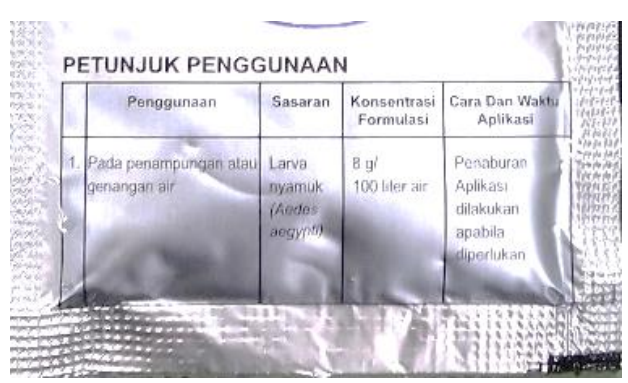

(b)

Gambar 1. Perbedaan petunjuk penggunaan pada kemasan (a) temephos 10g/100 Lair (10G) dan (b) temephos 8 gram/100 L air (10G).

\section{Uji Mortalitas Larva}

Larva instar III Ae. aegypti dari masing-masing strain dilakukan rearing dalam kondisi laboratorium yang terkontrol (kelembaban ruangan $75 \%$, temperatur air $28^{\circ} \mathrm{C}-30^{\circ} \mathrm{C}$, temperatur ruangan $28^{\circ} \mathrm{C}$ )dalam wadah plastik berisi air PDAM yang telah diendapkan sebelumnya selama semalam. Larva Ae. Aegypti JEM yang digunakan dalam penelitian adalah F3, larva SBY dari generasi F2, dan larva LAB merupakan generasi $\mathrm{F}_{313}$. Larva kemudian dibagi menjadi 15 kelompok berdasarkan perlakuan (kontrol, temephos $10 \mathrm{G}$ dosis $1 \mathrm{mg} / \mathrm{L} ; 0,5 \mathrm{mg} / \mathrm{L}$; $0,25 \mathrm{mg} / \mathrm{L} ; 0,125 \mathrm{mg} / \mathrm{L} ; 0,0625 \mathrm{mg} / \mathrm{L}, 0,03125$ $\mathrm{mg} / \mathrm{L} ; 0,015625 \mathrm{mg} / \mathrm{L}$, dan temephos $8 \mathrm{G}$ dosis 1 $\mathrm{mg} / \mathrm{L} ; 0,5 \mathrm{mg} / \mathrm{L} ; 0,25 \mathrm{mg} / \mathrm{L} ; 0,125 \mathrm{mg} / \mathrm{L} ; 0,0625$ $\mathrm{mg} / \mathrm{L}, 0,03125 \mathrm{mg} / \mathrm{L} ; 0,015625 \mathrm{mg} / \mathrm{L})$. Sebanyak
20 ekor larva diletakkan dalam setiap wadah plastik berisi air dan ditambahkan konsentrasi temephos sesuai perlakuan. Replikasi sebanyak 4 kali dilakukan untuk setiap perlakuan. Larva dipapar temephosselama 24 jam sesuai dengan ketentuan uji dari WHO(World Health Organization, 2016). Mortalitas larva pada masing-masing perlakuan dicatat dan dihitung presentasenya berdasarkan rumus berikut:

$$
M=\frac{a}{b} \times 100 \%
$$

Keterangan:

$\mathrm{M}=$ presentase mortalitas larva Ae. aegypti

$\mathrm{a}=$ jumlah larva Ae. aegypti yang mati

$\mathrm{b}=$ jumlah larva Ae. aegypti yang digunakan dalam perlakuan 


\section{Analisis data}

Data mortalitas larva Ae. aegypti dianalisis secara statistik menggunakan uji normalitas Kolmogorov-Smirnov, kemudian uji ANOVA satu arah yang dilanjutkan dengan uji post-hoc Duncan $\quad(p=0,05)$. Data $\mathrm{LC}_{95}$ ditentukan menggunakan regresi linear dari data mortalitas. Rasio resistensi ( $\left(R_{95}\right)$ dihitung dengan menggunakan persamaan berikut:

$$
R R_{95}=\frac{L C_{95} \text { populasi sampel }}{L C_{95} \text { populasi pembanding }}
$$

Keterangan:

$\mathrm{RR}_{95}=$ rasio resistensi Ae. aegypti pada konsentrasi letal 95

$\mathrm{LC}_{95}=$ konsentrasi letal 95

Tingkat resistensi ditentukan berdasarkan kategori dari penelitian sebelumnya (Mazzarri \& Georghiou, 1995). Larva Ae. aegypti diindikasikan memiliki resistensi rendah jika nilai
$\mathrm{RR}_{95}<5$, resistensi sedang jika $\mathrm{RR}_{95}$ antara 5-10, dan resistensi tinggi jika $R R_{95}>10$.

\section{HASIL}

Berdasarkan uji mortalitas dua jenis dosis temephos yang beredar secara komersil, larva Ae. aegyptiyang dikoleksi dari berbagai lokasi di Jawa Timur ditemukan masih rentan terhadap temephoskomersial. Sebagian besar dari mortalitas pada semua kelompok perlakuan $A e$. aegypti terjadi pada ambang batas menit ke-240 dan pada waktu 24 jam semua larva pada kelompok perlakuan temephos telah mengalami mortalitas. Data mortalitas pada titik waktu 240 menit kemudian dianalisis untuk menentukan LC 90 pada ambang batas waktu ini (Tabel 1). Pada dosis terendah yang digunakan dalam penelitian ini $(0,015625 \mathrm{mg} / \mathrm{L})$, rata-rata $>90 \%$ larva dari semua populasi mengalami kematian, baik pada temephos $10 \mathrm{G}$ maupun $8 \mathrm{G}$.

Tabel 1. Presentase mortalitas larva Ae. aegypti dari berbagai daerah di Jawa Timur dengan ambang waktu 240 menit.pada berbagai dosis temephos komersial

\begin{tabular}{clccc}
\hline \multirow{2}{*}{$\begin{array}{c}\text { Jenis } \\
\text { temephos }\end{array}$} & Dosis $(\mathbf{m g} / \mathbf{L})$ & \multicolumn{3}{c}{ Rata-rata mortalitas populasi larva (\%) pada 240 menit* } \\
\cline { 2 - 4 } $10 \mathrm{G}$ & 0 & $0,00 \pm 0,00^{\mathrm{a}}$ & $0,00 \pm 0,00^{\mathrm{a}}$ & LAB \\
\hline & 1 & $100,00 \pm 0,00^{\mathrm{b}}$ & $100,00 \pm 0,00^{\mathrm{b}}$ & $100,00 \pm 0,00^{\mathrm{a}}$ \\
& 0,5 & $100,00 \pm 0,0^{\mathrm{b}}$ & $100,00 \pm 0,00^{\mathrm{b}}$ & $100,00 \pm 0,00^{\mathrm{b}}$ \\
& 0,25 & $100,00 \pm 0,00^{\mathrm{b}}$ & $100,00 \pm 0,00^{\mathrm{b}}$ & $100,00 \pm 0,00^{\mathrm{b}}$ \\
& 0,125 & $97,50 \pm 5,00^{\mathrm{bc}}$ & $97,50 \pm 4,33^{\mathrm{b}}$ & $100,00 \pm 0,00^{\mathrm{b}}$ \\
& 0,0625 & $96,25 \pm 2,50^{\mathrm{bc}}$ & $96,25 \pm 6,50^{\mathrm{b}}$ & $95,00 \pm 7,07^{\mathrm{b}}$ \\
& 0,03125 & $95,00 \pm 4,08^{\mathrm{c}}$ & $96,25 \pm 6,50^{\mathrm{b}}$ & $96,25 \pm 4,79^{\mathrm{b}}$ \\
& 0,015625 & $95,00 \pm 4,08^{\mathrm{c}}$ & $95,00 \pm 8,66^{\mathrm{b}}$ & $96,25 \pm 4,79^{\mathrm{b}}$ \\
& 0 & $0,00 \pm 0,00^{\mathrm{a}}$ & $0,00 \pm 0,00^{\mathrm{a}}$ & $0,00 \pm 0,00^{\mathrm{a}}$ \\
& 1 & $100,00 \pm 0,00^{\mathrm{b}}$ & $100,00 \pm 0,00^{\mathrm{b}}$ & $100,00 \pm 0,00^{\mathrm{b}}$ \\
& 0,5 & $100,00 \pm 0,00^{\mathrm{b}}$ & $100,00 \pm 0,00^{\mathrm{b}}$ & $100,00 \pm 0,00^{\mathrm{b}}$ \\
& 0,25 & $100,00 \pm 0,00^{\mathrm{b}}$ & $100,00 \pm 0,00^{\mathrm{b}}$ & $100,00 \pm 0,00^{\mathrm{b}}$ \\
& 0,125 & $97,50 \pm 4,33^{\mathrm{b}}$ & $100,00 \pm 0,00^{\mathrm{b}}$ & $100,00 \pm 0,00^{\mathrm{b}}$ \\
& 0,0625 & $97,50 \pm 2,50^{\mathrm{b}}$ & $98,75 \pm 2,50^{\mathrm{b}}$ & $97,50 \pm 2,89^{\mathrm{bc}}$ \\
& 0,03125 & $95,00 \pm 6,12^{\mathrm{bc}}$ & $93,75 \pm 9,46^{\mathrm{b}}$ & $96,25 \pm 4,79^{\mathrm{bc}}$ \\
& 0,015625 & $91,25 \pm 5,45^{\mathrm{c}}$ & $93,75 \pm 12,50^{\mathrm{b}}$ & $95,00 \pm 4,08^{\mathrm{c}}$ \\
\hline
\end{tabular}

Keterangan: *) notasi berbeda menandakan hasil signifikan dari uji Duncan $(\mathrm{p}=0,05)$ 
Berdasarkan uji statistik, terdapat perbedaan signifikan antara kontrol yang tidak diberikan temephos dengan semua kelompok perlakuan yang diberikan temephos, baik $10 \mathrm{G}$ maupun $8 \mathrm{G}$. Perbedaan mortalitas larva yang signifikan antara dosis tertinggi $(1 \mathrm{mg} / \mathrm{L})$ dengan dosis terendah $(0,015625 \mathrm{mg} / \mathrm{L})$ ditemukan pada kelompok JEM, baik pada temephos $10 \mathrm{G}$ maupun $8 \mathrm{G}$, serta pada kelompok LAB pada dosis 8 G. Sedangkan kelompok SBY tidak menunjukkan perbedaan respon mortalitas yang signifikan antara dosis tertinggi (1 $\mathrm{mg} / \mathrm{L})$ hingga dosis terendah $(0,015625 \mathrm{mg} / \mathrm{L})$, baik pada penggunaan temephos $10 \mathrm{G}$ maupun $8 \mathrm{G}$. Data mortalitas kemudian digunakan untuk menentukan $\mathrm{LC}_{95}$ (Tabel 2).

Tabel 2. Lethal concentration95 (LC95) temephos komersial pada larva Ae. aegypti dari berbagai daerah di Jawa Timur dengan ambang waktu 240 menit,

\begin{tabular}{ccc}
\hline \multirow{2}{*}{ Populasi } & \multicolumn{2}{c}{$\mathbf{L C} \mathbf{9 5}(\mathrm{mg} / \mathrm{L})$} \\
\cline { 2 - 3 } & Temephos $\mathbf{1 0 ~ G}$ & Temephos $\mathbf{8 ~ G}$ \\
\hline JEM & $2,05 \times 10^{-2}$ & $3,92 \times 10^{-2}$ \\
SBY & $1,50 \times 10^{-2}$ & $2,05 \times 10^{-2}$ \\
LAB & $1,97 \times 10^{-2}$ & $9,04 \times 10^{-3}$ \\
\hline
\end{tabular}

Berdasarkan nilai $\mathrm{LC}_{95}$ untuk masing-masing dosis temephos. $\mathrm{RR}_{95}$ ditentukan untuk populasi SBY dan JEM dengan populasi LAB sebagai populasi pembanding (Tabel 3). Rasio resistensi temephosuntuk kedua populasi masih berada di bawah batas resistensi rendah $\left(\mathrm{RR}_{95}<5\right)$.

Tabel 3. Rasio resistensi 95 ( $\left.\mathrm{RR}_{95}\right)$ temephos komersial pada populasi larva Ae. aegypti dari Jawa Timur

\begin{tabular}{ccc}
\hline \multirow{2}{*}{ Populasi } & \multicolumn{2}{c}{ RR95 } \\
\cline { 2 - 3 } & Temephos 10 G & Temephos 8 G \\
\hline JEM & 1,04 & 4,34 \\
SBY & 0,76 & 2,26 \\
\hline
\end{tabular}

\section{PEMBAHASAN}

Indonesia sebagai negara tropis yang merupakan endemik penyakit dengue telah lama menghadapi penyakit ini sebagai beban kesehatan masyarakat. Selama ini,cara utama yang dilakukan untuk menekan penularan penyakit ini adalah dengan mengendalikan populasi vektor dengue di Indonesia, terutama Ae. aegypti. Salah satu metode yang dilakukan adalah dengan menambahkan larvasida pada genangan air yang menjadi lokasi preferensi bertelur Ae. aegypti.

Temephos telah lama digunakan sebagai larvasida untuk mengendalikan populasi $A e$. aegypti di Indonesia. WHO menyarankan penggunaan temephospada dosis $0,012 \mathrm{mg} / \mathrm{L}$, tetapi dosis operasional temephos yang digunakan di Indonesia adalah $1 \mathrm{mg} / \mathrm{L}$ (Haryanto, 2018; Mulyatno et al., 2012).Penaburan temephos mempunyai efek residu 3 bulan dengan pola pemakaian air secara normal. Temephos mempunyai tingkat toksisitas moderat akut apabila paparan melalui jalur dermal atau oral, dan toksisitas rendah apabila paparan melalui jalur inhalasi(USA - EPA, 2009).

Pada penelitian ini, larva dari ketiga populasi ditemukan masih rentanterhadap temephos pada dosis yang rendah $(0,015625 \mathrm{mg} / \mathrm{L})$,sebesar 1/64dari dosis operasional temephosyang disarankan oleh Kementrian Kesehatan Republik Indonesia pada ambang waktu 240 menit. Perbedaan respons mortalitas signifikan antara dosis tertinggi $(1 \mathrm{mg} / \mathrm{L})$ dengan dosis terendah $(0,015625 \mathrm{mg} / \mathrm{L})$ ditemukan pada kelompok JEM, baik pada temephos $10 \mathrm{G}$ maupun $8 \mathrm{G}$, serta pada kelompok LAB pada dosis 8 G. Sedangkan kelompok SBY tidak menunjukkan perbedaan respon mortalitas pada dosis atau jenis temephos yang berbeda. Konsentrasi letal 95 (LC95) untuk ketiga kelompok larva ditemukan pada di dosis yang rendah. Sementara itu, rasio resistensi (RR95) dari populasi SBY dan JEM juga masih berada di tingkatan yang rendah $(<5)$ dibandingkan dengan populasi LAB sebagai pembanding, baik pada temephos $10 \mathrm{G}$ maupun 8 G.

Adanya perbedaan respon mortalitas antara satu kelompok dengan kelompok lain menunjukkan perubahan resistensi temephos dalam populasi larva. Meskipun demikian, semua kelompok yang diuji dalam penelitian ini masih mengalami mortalitas di atas $90 \%$ pada dosis $0,015625 \mathrm{mg} / \mathrm{L}$ dan memiliki rasio resistensi yang 
rendah, menunjukkan kerentanan pada temephos. Hal ini berbeda dengan populasi larva $A e$. aegyptidariTegal yang menunjukkan respons mortalitas sebesar $90 \%$ pada dosis yang lebih tinggi $(0,025 \mathrm{ppm})$, mengindikasikan potensi resistensi pada larva dari Tegal (Kresnadi et al., 2021).

Penggunaan temephospada dosis yang terlalu tinggi dan secara terus menerus kemungkinan dapat menginduksi resistensi organophosphatetemephos, sebagaimana yang mulai diindikasikan pada beberapa populasi $A e$. aegyptidari beberapa daerah di Indonesia, antara lain Demak, Klaten, Banjarnegara(Ikawati et al., 2017), Padang(Hasmiwati et al., 2018), dan Surabaya(Mulyatno et al., 2012).Larva Ae. aegypti mampu melakukan detoksifikasi larvasida yang masuk ke tubuhnya oleh karena peranan enzim detoksifikasi glutathione $S$ transferase (GST), esterase, dan monooxygenase. Pada strain larva Ae. aegypti yang mengalami resistensi organophosphatetemephos, ekspresi GST dan esterase ditemukan meningkat dibandingkan strain yang masih rentan (MeloSantos et al., 2010; Paeporn et al., 2003). LarvaAe. aegypti yang memiliki resistensi terhadap insektisida pyrethroid di beberapa daerah di Indonesia memiliki level enzim oksidase dan esterase yang lebih tinggi secara signifikan dibadingkan dengan strain yang rentan(Ahmad et al., 2007). Peningkatan enzim esterase juga ditemukan pada sampel Ae. aegypti resisten moderat terhadap larvasida organophosphatemalathiondan cypermethrin dari daerah Yogyakarta(Mulyaningsih et al., 2018). Peningkatan ekspresi enzim-enzim detoksifikasi menyebabkan larva Ae. aegypti menjadi lebih toleran terhadap keberadaan larvasida.

Untuk mencegah kemunculan strain Ae. aegypti resisten lebih lanjut, dosis larvasida temephos yang digunakan secara luas sebaiknya ditinjau ulang. Sebagaimana diindikasikan pada penelitian ini, populasi Ae, aegypti dari Jawa Timur masih rentan mengalami mortalitas akibat larvasida temephos pada dosis yang rendah.
Pengujian lebih lanjut diperlukan untuk menentukan konsentasi temephos yang lebih rendah dari dosis operasional tetapi masih efektif untuk mengendalikan vektor Ae. aegypti.

\section{SIMPULAN}

Larva Aedes aegypti yang berasal dari berbagai daerah di Jawa Timur, masih memiliki kerentanan pada dosis rendah temephos komersial yang beredar, baik dosis $8 \mathrm{G}$ maupun $10 \mathrm{G}$. Larva $A e$. aegypti mengalami $>90 \%$ mortalitas pada dosis temephos yang rendah $(0,015625 \mathrm{mg} / \mathrm{L})$. Kerentanan larva pada dosis rendah temephos komersial dapat digunakan sebagai dasar untuk menurunkan dosis operasional penggunaan temephoskomersial untuk larvasida Ae. aegypti di Jawa Timur. Penelitian lebih lanjut dapat difokuskan untuk melihat apakah larva $A e$. aegypti di daerah lain juga memilikikerentanan serupa terhadap temephos komersial dan menentukan dosis operasional temephos yang lebih tepat untuk menekan munculnya strain Ae.aegypti yang resisten terhadap temephos.

\section{KEPUSTAKAAN}

Ahmad I, Astari S, Tan M. 2007. Resistance of Aedes aegypti (Diptera: Culicidae) in 2006 to pyrethroid insecticides in Indonesia and its association with oxidase and esterase levels. Pakistan Journal of Biological Sciences 10(20): $\quad 3688-3692 . \quad$ DOI: 10.3923/pjbs.2007.3688.3692

Ding F, Fu J, Jiang D, Hao M, Lin G. 2018. Mapping the spatial distribution of Aedes aegypti and Aedes albopictus. Acta Tropica 178(1): $155-162 . \quad$ DOI: 10.1016/j.actatropica.2017.11.020

Haryanto B. 2018. Indonesia Dengue Fever: Status, Vulnerability, and Challenges. Current Topics in Tropical Emerging Diseases and Travel Medicine. IntechOpen, 12. DOI: 10.5772/intechopen. 82290

Hasmiwati, Rusjdi SR, Nofita E. 2018. Detection of ace-1 gene with insecticides resistance in aedes aegypti populations from DHFendemic areas in Padang, Indonesia. 
Biodiversitas 19(1): $\quad 31-36 . \quad$ DOI: 10.13057/biodiv/d190105

Ikawati B, Sunaryo, Wahyudi BF. 2017. Aedes aegypti resistance to temephos in Central Java, Indonesia. Advanced Science Letters 23(4): $\quad 3544-3546 . \quad$ DOI: 10.1166/asl.2017.9163

Kemenkes RI. 2019. Profil Kesehatan Indonesia 2018 [Indonesia Health Profile 2018].

Kraemer MUG, Sinka ME, Duda KA, Mylne AQN, Shearer FM, Barker CM, Moore CG, Carvalho RG, Coelho GE, Van Bortel W, Hendrickx G, Schaffner F, Elyazar IR, Teng HJ, Brady OJ, Messina JP, Pigott DM, Scott TW, Smith DL, William Wint GR, Golding N, Hay SI. 2015. The global distribution of the arbovirus vectors Aedes aegypti and Ae. Albopictus. elife 4: e08347. DOI: 10.7554/eLife.08347

Kresnadi I, Amin BF, Ariq H, Akbar VA, Winita R, Ridhawati S, Lisawati S, Firmansyah NE, Wibowo H. 2021. The Susceptibility of Aedes aegypti in Dengue Endemic Areas, Tegal, Central Java Indonesia. Balaba: Jurnal Litbang Pengendalian Penyakit Bersumber Binatang Banjarnegara 17(1): 11-18

Mazzarri MB, Georghiou GP. 1995. Characterization of resistance to organophosphate, carbamate, and pyrethroid insecticides in field populations of Aedes aegypti from Venezuela. Journal of the American Mosquito Control Association 11(3): 315-322

Melo-Santos MAV, Varjal-Melo JJM, Araújo AP, Gomes TCS, Paiva MHS, Regis LN, Furtado AF, Magalhaes T, Macoris MLG, Andrighetti MTM, Ayres CFJ. 2010.
Resistance to the organophosphate temephos: Mechanisms, evolution and reversion in an Aedes aegypti laboratory strain from Brazil. Acta Tropica 113(2): 180 189. DOI: $10.1016 /$ j.actatropica.2009.10.015 Mulyaningsih B, Umniyati SR, Satoto TBT, Diptyanusa A, Nugrahaningsih DAA, Selian Y. 2018. Insecticide resistance and mechanisms of Aedes aegypti (Diptera: Culicidae) in Yogyakarta. Journal of thee Medical Sciences (Berkala Ilmu Kedokteran)50(01): 24-32. DOI: 10.19106/jmedsci005001201803

Mulyatno KC, Yamanaka A, Ngadino, Konishi E. 2012. Resistance of Aedes aegypti (L.) larvae to temephos in Surabaya, Indonesia. Southeast Asian Journal of Tropical Medicine and Public Health 43(1): 29-33

Paeporn P, Komalamisra N, Deesin V, Rongsriyam Y, Eshita Y, Thongrungkiat S. 2003. Temephos resistance in two forms of Aedes aegypti and its significance for the resistance mechanism. Southeast Asian Journal of Tropical Medicine and Public Health 34(4): 786-792

Tang SCN, Rusli M, Lestari P. 2020. Climate Variability and Dengue Hemorrhagic Fever in Surabaya, East Java, Indonesia. Indian Journal of Public Health Research \& Development11(2): $131 . \quad$ DOI: 10.37506/v11/i2/2020/ijphrd/194770

USA - EPA. 2000. Temephos: Revised HED Chapter for the Registration Eligibility Decision (RED) Document.

World Health Organization (WHO). 2016. Monitoring and Managing Insecticide Resistance in Aedes mosquito Populations. 